\title{
Strajk sierpniowy i Solidarność (1980-1981) widziane z gdańskich męskich domów zakonnych
}

Jednym z przełomowych momentów w historii Polski był wybór kardynała Karola Wojtyły na papieża w 1978 roku. Reakcja samego społeczeństwa oraz pielgrzymki papieskie (1979) wymusiły na władzach zmianę polityki wobec Kościoła katolickiego. Kolejne wydarzenia potoczyły się szybko: strajki sierpniowe w 1980 roku, powstanie Niezależnego Samorządnego Związku Zawodowego "Solidarność", wprowadzenie stanu wojennego w grudniu 1981. We wszystkie te wydarzenia zaangażowali się przedstawiciele duchowieństwa Kościoła katolickiego, również zakonnego ${ }^{1}$. W wywiadzie z Jackiem Żakowskim ojciec Ludwik Wiśniewski OP, dominikanin, mówił: „towarzyszyć ludziom, być z ludźmi - nie tylko wtedy, kiedy przychodzą do kościoła. [...] Posługa duszpasterska nie może więc ograniczać się do ołtarza i konfesjonału. Musi obejmować i to, co pan nazywa sprawami społecznymi. [...] To jest konieczne do zweryfikowania, dla potwierdzenia tego, co [kapłan] głosi w kościele"2.

Warto podjąć próbę przebadania, w jaki sposób zachowywały się wobec wydarzeń z lat 1980-1981 wspólnoty domów zakonnych lub klasztorów oraz poszczególni zakonnicy w diecezji gdańskiej. Zagadnienie jest tym bardziej ciekawe, że od dnia wybuchu strajku część z nich znajdowała się w samym centrum wydarzeń. W 1980 roku na terenie diecezji pracowali: saletyni na Wyspie Sobieszewskiej (parafia Matki Bożej Saletyńskiej), pallotyni w ścisłym centrum Gdańska (kościół św. Elżbiety Węgierskiej) oraz we Wrzeszczu (kaplica Matki Bożej Częstochowskiej), jezuici w centrum Gdańska (kościół św. Bartłomieja) oraz we Wrzeszczu (kościół św. Andrzeja Boboli, parafia Krzyża Świętego), karmelici bosi i bracia szkolni (domy zakonne w Sopocie), reformaci w Nowym Porcie (kościół Niepokalanego Serca Maryi), kapucyni (kościół św. Jakuba), karmelici (kościół św. Katarzyny Aleksandryjskiej), franciszkanie konwentualni (parafia i kościół Świętej Trójcy), dominikanie (parafia z bazyliką mniejszą,

1. J. Marecki, Państwo a Kościół katolicki w latach 1945-1989. Walka o "rząd dusz", [w:] Polityka władz państwowych wobec Kościoła katolickiego na Pomorzu Zachodnim i ziemi lubuskiej w latach 1945-1989, pod red. T. Ceynowy i P. Knapa, Szczecin 2010, s. 22.

2. Rozmowa z Jackiem Żakowskim pod tytułem Świadectwo została opublikowana w: „Powściągliwość i Praca" 1984, nr 6 (391). Zob. też L. Wiśniewski, Nigdy nie układaj się ze złem. Pięćdziesią lat zmagań o Kościół i Polskę, Kraków-Rzeszów 2018, s. 124.

\section{LESZEK MOLENDOWSKI}

Muzeum Gdańska

ORCID: 0000-0002-3756-7321 
kościołem św. Mikołaja), cystersi w Oliwie (kościół Matki Bożej Królowej Korony Polskiej), oblaci (kościół św. Józefa), księża zmartwychwstańcy (kościół parafialny Zmartwychwstania Pańskiego), jak również księża misjonarze prowadzący Gdańskie Seminarium Duchowne ${ }^{3}$.

Najważniejszymi źródłami, do których należało sięgnąć, były archiwa poszczególnych zakonów i domów, w szczególności kroniki. Nie wszystkie zakony je udostępniają, nie we wszystkich archiwach znalazły się materiały odnoszące się do badanego zagadnienia. Nie zawsze księża byli też na tyle odważni, by eksponować swoje poglądy. Dlatego należało również sięgnąć po źródła państwowe: Archiwum Akt Nowych, Archiwum Państwowego w Gdańsku oraz Instytutu Pamięci Narodowej.

\section{Zakony a strajk sierpniowy w Stoczni Gdańskiej}

Strajk w Stoczni Gdańskiej im. Lenina rozpoczął się w czwartek 14 sierpnia 1980 roku i od początku miał ekonomiczno-polityczny charakter, a także wysoki stopień organizacji. 16 sierpnia powstał Międzyzakładowy Komitet Strajkowy (MKS), a do prezydium wybrano Lecha Wałęsę (przewodniczący) oraz Andrzeja Gwiazdę i Bogdana Lisa (wiceprzewodniczący). Spisano 21 postulatów MKS-u, między innymi przyznanie prawa do tworzenia wolnych od partii związków zawodowych. Pierwszą mszę dla strajkujących stoczniowców odprawił 17 sierpnia ksiądz Henryk Jankowski, proboszcz parafii św.
Brygidy, na której terenie leżała stocznia. Nastąpiło to w wyniku ustaleń podjętych przez biskupa Lecha Kaczmarka i jego sufragana księdza Kazimierza Kluza z miejscowymi władzami ${ }^{4}$. Już 18 sierpnia strajk wsparła załoga Stoczni Szczecińskiej. Przeciwnie do wydarzeń z grudnia 1970 roku zawiązała się współpraca robotników i inteligencji, która okaże się filarem Solidarności ${ }^{5}$. Wybuch strajków stanowił całkowite zaskoczenie dla władz komunistycznych. Znacznie lepiej w tych okolicznościach orientował się Kościół, który ustami kardynała Stefana Wyszyńskiego kilkukrotnie sygnalizował władzom powage sytuacji. Prymas wypowiedział się w sprawie strajków w czasie nabożeństwa w Wambierzycach Śląskich 17 sierpnia, mówiąc, że "świat robotniczy podejmuje starania o należne Narodowi prawa społeczne, moralne, ekonomiczne" ${ }^{\prime \prime}$. Relacje w trójkącie Kościół-władza-Solidarność miały w okresie od sierpnia 1980 do grudnia 1981 roku kluczowe znaczenie dla władz i ich dygnitarzy. Władze starały się przeciwdziałać zbytniemu zbliżeniu między duchowieństwem a opozycją, z drugiej strony zaś wykorzystywać autorytet Kościoła do uspokajania nastrojów społecznych ${ }^{7}$.

Strajkujący z całą pewnością oczekiwali przychylności ordynariusza diecezji, biskupa Kaczmarka. On jednak starał się trzymać $\mathrm{z}$ dala od działalności politycznej. Tego samego wymagał od podległego mu duchowieństwa, w tym i od zakonników. Nie zamierzał angażować Kościoła w polityczny konflikt. W rozmowie $\mathrm{z}$ wojewodą Jerzym Koło-

3. Na podstawie: Schematyzm Diecezji Gdańskiej rok 1980, Gdańsk 1980, s. 118-119, 125-129, 133-134, 137-139, 142-143, 145-146, 183-193.

4. S. Bogdanowicz, Lech Kaczmarek. Biskup Gdański, Gdańsk 1994, s. 222 i n.; A. Dudek, R. Gryz, Komuniści i Kościół w Polsce (1945-1989), Kraków 2006, s. 352; M.S. Mazgaj, Church and State in Communist Poland. A History, 1944-1989, JeffersonLondon 2010, s. 124-125.

5. Na temat strajków w sierpniu 1980 roku, jak i na temat okresu działalności legalnej NSZZ "Solidarność" zob. szerzej: A. Friszke, Rewolucja Solidarności 1980-1981, Kraków 2014, s. 21-74 i n.; idem, Polska. Losy państwa i narodu. 1939-1989, Warszawa 2003, s. 367-370; T. Kozłowski, Anatomia rewolucji. Narodziny ruchu społecznego "Solidarność" w 1980 roku, Warszawa 2017, s. 36-159; L. Biernacki, A. Kazański, NSZZ "Solidarność" Region Gdański, [w:] NSZZ Solidarność 1980-1989, t. 3: Polska północna, pod red. Ł. Kamińskiego i G. Waligóry, Warszawa 2010, s. 7-246; Czas przełomu. Solidarność 1980-1981, pod red. W. Polaka, P. Ruchlewskiego, V. Kmiecik, J. Kufla, Gdańsk 2010.

6. R. Łatka, Polityka władz PRL wobec Kościoła katolickiego w województwie krakowskim w latach 1980-1989, Kraków 2016, s. 127.

7. Ibidem, s. 128-129. 
dziejskim, która odbyła się 15 sierpnia w Urzędzie Wojewódzkim, biskup mówił, że apelowałby o spokój i zakończenie strajku. W obecności wojewody i biskupa funkcjonariusz SB powiedział, że na terenie stoczni podjęli już jakąś działalność księża zakonni. Według niego widziani tam byli jezuici i dominikanie ${ }^{9}$. Jednym z najaktywniejszych dominikanów zaangażowanych w Gdańsku w działalność na rzecz Solidarności był ojciec Sławomir Słoma 0P z kościoła św. Mikołaja, duszpasterz akademicki. Studenci i wykładowcy, z którymi się stykał i wśród których pracował, pisali o nim: „zawsze tam obecny, gdzie najbardziej potrzebny [...]; zdobył poważanie i szacunek w środowisku studenckim i nauczycieli akademickich"10. W tym czasie w kronice klasztoru Dominikanów odnotowano: "Gdańsk - Gdynia Kołobrzeg - Szczecin, dołączyły się Elbląg i trwa i ogarnia inne zakłady"11. Warto zauważyć, że protesty latem 1980 roku postawiły przed Kościołem nowe wyzwanie. Znaczące w tym kontekście jest orędzie biskupa Kaczmarka z 23 sierpnia 1980 roku, w którym wykazywał on zrozumienie dla strajkujących robotników, pisząc jednocześnie: „Wszystko jednak musi odbywać się $\mathrm{w}$ atmosferze rozwagi, godności, wzajemnego zrozumienia i bez nienawiści"12. Ksiądz Stanisław Bogdanowicz, biograf biskupa, zauważa, że były to słowa duszpasterza, nie polityka, i należy je pamiętać, ponieważ oddawały nastrój tamtych dni ${ }^{13}$.

Kościół wkraczał do zakładów pracy, a więc do miejsc, do których dotychczas władze komunistyczne zabraniały mu wstępu ${ }^{14}$. W charakterze spowiednika do strajkujących stoczniowców przychodził z pobliskiego kościoła św. Jakuba ojciec Przemysław Zygmunt Knap 0FMCap, kapucyn, przełożony domu ${ }^{15}$. Podczas mszy odprawianych w stoczni spowiadał również ksiądz Jerzy Romanowicz SAC, pallotyn z kościoła św. Elżbiety ${ }^{16}$. Kronikarz i zarazem gwardian klasztoru Franciszkanów Konwentualnych w Gdańsku (przy kościele Świętej Trójcy), ojciec Mieczysław Władysław Seroczyński OFMConv., w swych zapiskach nie komentował zbyt obszernie wydarzeń, które zaczęły rozgrywać się w Polsce. W nielicznych fragmentach da się jednak zauważyć sympatię do opozycji i nowego ruchu społecznego ${ }^{17}$. Dużo częściej swe poglądy zakonnicy wyrażano pośrednio w suplikacjach i modlitwach ${ }^{18}$.

W domu zakonnym pallotynów przy kościele św. Elżbiety, przy samym Komitecie Wojewódzkim PZPR, gościli między innymi Tadeusz Mazowiecki i Bronisław Geremek. W towarzystwie księdza Jerzego Błaszczaka SAC przedostawali się do stoczni. Dom pallotynów był niemal idealnym miejscem do zatrzymania się w Gdańsku, położony bardzo blisko

8. A. Friszke, Rewolucja Solidarności..., s. 43.

9. S. Bogdanowicz, Kościół gdański pod rządami komunizmu 1945-1984, Gdańsk 2000, s. 363-364.

10. M. Grubka, Działania władz państwowych i kościelnych wobec gdańskiego duszpasterstwa akademickiego o. Sławomira Słomy OP (1979-1985), [w:] Komunistyczny aparat represji wobec Polskiej Prowincji Dominikanów, pod red. M. Miławickiego i M. Wenklara, Kraków 2015, s. 279-280.

11. Archiwum Klasztoru 0jców Dominikanów w Gdańsku [dalej: AKODG], Kronika klasztoru dominikanów Gdańsk 1979-1992, b.p.

12. S. Bogdanowicz, Lech Kaczmarek, s. 222.

13. Ibidem.

14. D. Zamiatała, Zakony męskie w polityce władz komunistycznych w Polsce w latach 1945-1989, t. 2: Działalność duszpasterska i społeczna zakonów w latach 1945-1989, Warszawa 2012, s. 64.

15. A. Szarszewski, A. Szarszewska, Przełożeni domu zakonnego Braci Mniejszych Kapucynów w Gdańsku, [w:] Między Gdańskiem a Santiago. 600-lecie konsekracji kościoła św. Jakuba fundacji szyprów w Gdańsku, pod red. B. Sieka, A. Szerszewskiego, P. Paluchowskiego, Gdańsk 2015, s. 266.

16. D. Gucewicz, W cieniu Komitetu Wojewódzkiego. "Wroga" działalność pallotynów z kościoła św. Elżbiety w Gdańsku przełomu lat siedemdziesiątych i osiemdziesiątych XX wieku, [w:] Księża dla władzy groźni. Duchowni współpracujący z opozycją (1976-1989), pod red. R. Eatki, Warszawa 2019, s. 156.

17. Archiwum Klasztoru Franciszkanów w Gdańsku [dalej: AKFG], Kronika, b.p.

18. S. Bogdanowicz, Kościół św. Piotra i Pawła w Gdańsku, Gdańsk 1993, s. 90-91. 
Dworca Głównego PKP, jak i stoczni. Co ciekawe, portret Jana Pawła II, który zawisł potem na bramie nr 2 stoczni, wisiał właśnie w przedsionku domu pallotynów ${ }^{19}$. Gościnę u zakonników znalazł także zagraniczny dziennikarz, Włoch Luigi Geninazzi, z katolickiego tygodnika "Il Sabato". W swej książce wspominał on, że dzięki kontaktom z pallotynami nie miał większych problemów z dotarciem do najważniejszych osób zaangażowanych w wydarzenia strajkowe: Bronisława Geremka, Tadeusza Mazowieckiego, Andrzeja Wielowiejskiego, Bohdana Cywińskiego. Geninazzi wspomniał: „Dopisało mi szczęście. Podczas wielogodzinnych rozmów przy stole, gdzie wspólnie jedliśmy kolację, coś z Polski zaczynałem rozumieć. Niespodziewanie znalazłem się na spotkaniu, które przypominało tajny sobór duchownych i intelektualistów. Przywodzili mi na myśli karbonariuszy, organizujących osobliwy ruch rewolucyjny"20.

Ksiądz Eugeniusz Klimiński SAC, bliski współpracownik księdza Eugeniusza Dutkiewicza SAC, mieszkający i pracujący w domu zakonnym przy kaplicy Matki Bożej Częstochowskiej w Gdańsku-Wrzeszczu, przy Akademii Medycznej (dziś Gdański Uniwersytet Medyczny), po latach wspominał, że wielu członków wspólnoty pracowało w stoczni. W rodzący się związek zawodowy oraz ruch społeczny zaangażowało się wielu pracowników naukowych, a w wraz z nimi wielu studentów ${ }^{21}$. Ksiądz Klimiński SAC pisał, że stale gościli różnych ludzi z Europy, poruszonych tym, co dzieje się w Gdańsku. Przybywało jednocześnie „«ekspertów» z kraju - ludzi, którzy szczerze chcieli pomagać robotnikom". Cenne w tych dniach były też wizyty ludzi kultury. Jak to posumował ksiądz Klimiński: „Właściwie cały świat polskiej kultury ruszył do Gdańska - to «przymierze» inteligencji i świata pracy można nazwać fenomenem tamtego czasu"22. W tę samą niedzielę 17 sierpnia 1980 roku, gdy została odprawiona pierwsza msza w stoczni, w niektórych gdańskich świątyniach, w tym obu pallotyńskich, modlono się za robotników, aby w tych trudnych chwilach wspomagał ich Bóg i aby świat robotniczy był sprawiedliwie wynagradzany, za rządzących, a także o wolność prasy, słowa i wiary ${ }^{23}$. Pallotyni, pisząc o rozpoczęciu strajku, zwracali uwagę na jego masowy charakter, gdyż dołączały do niego kolejne zakłady z Polski, jak również na to, że poza robotnikami ze stoczni do strajku przystąpili również motorniczy tramwajów i kierowcy autobusów. Za ogromny sukces strajkujących uważali utworzenie "międzyzakładowego Komitetu Strajkowego do pertraktacji z władzami, które się przeciągają i nie widać końca"24. W czasie tychże wydarzeń pracownicy gdańskiej, ale i gdyńskiej stoczni, ale również - jak zauważył pallotyn - „nasze kościoły żyły nadzieją, może czasem zbyt dużym optymizmem, że idzie na naród nowe"25.

Również cystersi odnotowali wydarzenia sierpniowe, choć w dużo bardziej sprawozdawczy sposób: „W Stoczni Gdańskiej rozpoczął się strajk robotników i komunikacji miejskiej, którzy domagali się nowych związków zawodowych i większej wolności"26. Zmartwychwstańcy z parafii Zmartwychwstania Pańskiego z Gdańska-Wrzeszcza skupili się na opisie nastrojów w mieście. Ksiądz Stefan Duda CR, proboszcz parafii, odnotował wzrost napięcia, które "udziela się nam wszystkim". 17 sierpnia przypadała rocznica poświę-

\footnotetext{
19. D. Gucewicz, W cieniu Komitetu..., s. 156.

20. G. Geninazzi, Czerwona Atlantyda. Upadek komunizmu w Europie Wschodniej, przeł. A. Gołębiowska, Kraków 2014, s. 44-46.

21. E. Klimiński, Do niego należy czas. Pamiętnik duszpasterza, Warszawa 2007, s. 86.

22. Ksiądz Eugeniusz Dutkiewicz SAC. Ojciec ruchu hospicyjnego w Polsce, zbiór i oprac. P. Krakowiak i A. Stolarczyk, Gdańsk 2007, s. 63-64.

23. D. Gucewicz, W cieniu Komitetu..., s. 155.

24. Archiwum Domu Stowarzyszenia Apostolstwa Katolickiego w Gdańsku [dalej: ADSAK], Kronika Domu, t. 2: $1976-1984$, s. 85.

25. E. Klimiński, Do niego należy czas, s. 88.

26. Archiwum Klasztoru 0jcu Cystersów w Gdańsku-Oliwie [dalej: AKOCG0], Kronika 1945-2013 (odtworzona), s. 82.
} 
cenia kościoła i powołania parafii. Sumę w obecności okolicznych proboszczów odprawił biskup Kaczmarek. Po oficjalnych obchodach wszyscy rozmawiali i prosili o informacje o strajku od ordynariusza, również na temat mszy w stoczni. Tego dnia zmartwychwstańcy w czasie mszy wezwali do modlitwy wiernych za ojczyznę, „za robotników walczących o swoje prawa, za rządzących by szukali dobra narodu"27. Tego samego dnia ojciec Dominik Norbert Kabattek OFM, reformata z Nowego Portu (z kościoła rektorskiego Niepokalanego Serca Maryi), odebrał około godziny 7.30 telefon od Komitetu Strajkujących Portowców. Proszono go o odprawienie mszy na terenie portu. Zakonnik musiał jednak odmówić i podać numer telefonu do proboszcza, księdza Jana Gustkowicza, bez którego zgody nie mógł udać się z posługą ${ }^{28}$.

Zmartwychwstaniec ksiądz Stefan Duda CR 20 sierpnia był w stoczni. Tak to opisał: „Tłumy ludzi. Jedni przychodzą, drudzy odchodzą. Z drugiej strony ogrodzenia robotnicy w kombinezonach roboczych i hełmach ochronnych na głowach. 0czy roziskrzone. Na bramie obraz M. Boskiej Częstochowskiej [...] na murze obok portret Papieża i Orzeł Polski. Pasmo kwiatów przed bramą, na skraju skweru. Ludzie się modlą"29. W kronice klasztoru Franciszkanów Konwentualnych w Gdańsku pod datą 21 sierpnia 1980 roku czytamy: „W Gdańsku jak i w całej Polsce przeżywamy wielki niepokój. Stoczniowcy i wiele zakładów strajkuje, by wymusić zmiany w trudnej sytuacji gospodarczej i społecznej. Panuje jednak porządek i jest jakie takie zaopatrzenie. Modlimy się codziennie, by szczęśliwie rozwiązana została ta arcytrudna sytuacja"30.
23 sierpnia 1980 roku w klasztorze Reformatów zjawił się proboszcz ksiądz Jan Gustkowicz z przedstawicielami Komitetu Strajkowego i osobiście poprosił ojca Dominika Kabattka OFM o odprawianie mszy następnego dnia, w niedzielę 24 sierpnia, na co ten bardzo chętnie się zgodził. Proboszcz powiedział gwardianowi, że jeżeli z podobną prośbą zgłosi się jakikolwiek inny komitet, ma jego pozwolenie na to, aby zgodzić się na podobne prośby. Zgłosił się inny komitet ${ }^{31}$ i obie msze odprawił ojciec Dominik Kabattek OFM. Pierwsza odbyła się o godzinie 10.00 w Rejonie III, za kanałem portowym. Fiatem 126p przyjechali po niego trzej strajkujący. Po przepłynięciu na drugą stronę został przetransportowany syrenką pod stołówkę, gdzie miała zostać odprawiona msza. W kronice zapisano: „W stołówce, wielkiej prawie jak nasz kościół, był zbudowany ołtarz, a na ścianie nowy krzyż zrobiony przez robotników. Powiesili go w miejscu, gdzie wisiał do 1957"32. Punktualnie o godzinie 10.00 msza się rozpoczęła, a po niej odśpiewano „Boże, coś Polskę!". Ojciec Kabattek OFM powiedział, że Kościół jest zawsze $z$ ludem pracy. Następnie robotnicy wraz z zakonnikiem udali się do Rejonu I portu. Przed portową bramą stał tłum ludzi, przybyła pielgrzymka z Brzeźna. Na dachach magazynów znajdowali się żołnierze Wojsk Ochrony Pogranicza. W dużej stołówce zebrali się robotnicy, na ogół ubrani odświętnie. Ołtarz był udekorowany kwiatami, a obok ołtarza postawiono wysoki na półtora metra krzyż, wykonany w nocy przez stolarzy ${ }^{33}$.

27. Archiwum Parafii Niepokalanego Serca Marii w Gdańsku-Wrzeszczu [dalej: APNSMGW], Kronika parafialna (1970-1980), b.p.

28. Archiwum Klasztoru Reformatów w Nowym Porcie [dalej: AKRNP], Kronika 01, s. 453; B. Brzuszek, 0. Dominik Norbert Kabattek OFM. Duszpasterz portowców w Gdańsku-Nowym Porcie w latach 1980-1989, „Studia Franciszkańskie” 2017, nr 17, s. 96.

29. APNSMGW, Kronika parafialna, t. III, b.p.

30. AKFG, Kronika, b.p.

31. W. Nocny, Nowy Port. Pierwsza brama Gdańska, Gdańsk 2005, s. 162; AKRNP, Kronika 01, s. 453.

32. AKRNP, Kronika 01, s. 454.

33. Na ramionach krzyża umieszczono napis: „Zawsze z Bogiem”, na pionowej belce: „Krzyż na okoliczność dni strajku, data rozpoczęcia 15.08.80 - data zakończenia 31.08.80 [dopisano po zakończeniu strajku]. Msza św. 24.08.80. Rej. I. /WOC/"). Według woli robotników tenże krzyż miał znaleźć się w kościele Reformatów w Nowym Porcie jako wotum wdzięczności. AKRNP, Kronika 01, s. 456; B. Brzuszek, 0. Dominik Norbert Kabattek OFM, s. 97. 
Tego samego dnia, 23 sierpnia 1980 roku, oblat z klasztoru przy kościele rektorskim św. Józefa, ojciec Wacław Gospodarczyk 0MI, był z mszą oraz kazaniem w Przyjaźni, a ojciec Jacek Rzadkiewicz OMI o godzinie 17.00 odprawiał mszę w parafii św. Brygidy w zastępstwie proboszcza księdza Jankowskiego, który w stoczni odprawiał mszę, ",bo strajk solidarności trwa! Wieczorem zgromadzeni zakonnicy słuchali przemówienia I Sekretarza PZPR Edwarda Gierka"34. Również pallotyni zwrócili uwagę na przywódcę partii, który 24 sierpnia "w dramatycznym przemówieniu w telewizji” przyznawał się "do wielu błędów w prowadzeniu gospodarki krajowej, która jest opłakana"35. Różnie wydarzenia strajku sierpniowego były przez zakonników z gdańskich domów zakonnych i klasztorów przedstawiane oraz odbierane, ale jedno wydarzenie pojawia się we wszystkich sprawozdaniach - uroczysta msza w stoczni, coś, co do tej pory było nie do pomyślenia. Dominikanie z kościoła św. Mikołaja napisali: „W niedzielę była msza św. Ludzie za i sprzed bramy stoczni odmawiają różaniec, śpiewają pieśni religijne i patriotyczne. Trwa to już dziewięć dni, dziś nowe rozmowy z przedstawicielami Rządu"36. W ten dzień, w niedzielę 24 sierpnia 1980 roku, msze odbyły się w dziewięciu strajkujących zakładach. W Stoczni Gdańskiej w liturgii uczestniczyło około 2 tysięcy osób wewnątrz i 3,5 tysiąca na zewnątrz zakładu. Ksiądz Jankowski odczytał orędzie od biskupa Kaczmarka oraz wezwał zebranych do spokoju i rozwagi ${ }^{37} .25$ sierpnia w kościele pallotynów, św. Elżbiety, podczas mszy proszono o wytrwałość i rozwagę w działaniach strajkujących robotników, żeby kierowali się chrześcijańską miłością i wskazaniami Ewangelii ${ }^{38}$.
Oblaci z klasztoru gdańskiego przy kościele św. Józefa zauważyli: „niesłychane, na terenie stoczni gdańskiej, w niedzielę odprawiona była Msza św. przez ks. Proboszcza H. Jankowskiego [...] Nasi zaś ojcowie odprawiali w kościele parafialnym" ${ }^{39}$. Cystersi zauważyli również, że we wszystkich strajkujących zakładach kapłani odprawiali mszę i spowiadali, że robotnicy licznie przystępowali do komunii oraz że "wszyscy żyli w napięciu co będzie dalej, co wymyśli władza komunistyczna". Kronikarz ocenił strajk jako słuszny bunt, do którego siły robotnicy "czerpali od Boga dlatego obrazy religijne zawieszali na bramach zakładów”. Zaznaczał, że Kościół nie opuścił strajkujących ${ }^{40}$. Biskup Zygmunt Pawłowicz pisał, że od samego początku w strajkach uwydatnił się wymiar religijny. Na miejsca strajków przybywali księża odprawiający msze, modlący się i spowiadający robotników: „Tak było na Wybrzeżu, w Szczecinie, na Śląsku, na Dolnym Śląsku i we wszystkich innych regionach" ${ }^{\prime 1}$. Władze starały się zażegnać kryzys za pomocą ustępstw na polu ekonomicznym. Musiano jednak sięgnąć również po autorytet Kościoła i prymasa Wyszyńskiego. Zmanipulowano w tym celu jego kazanie wygłoszone na Jasnej Górze 26 sierpnia 1980 roku, które zawierało pozytywne dla władz fragmenty. Tylko szybkie zawarcie porozumień nie dopuściło do rozdźwięku między Kościołem a strajkującymi na tle tego kazania ${ }^{42}$. Dużą uwagę na słowa prymasa, jak i na działania władz zwrócili franciszkanie: „W dzień Matki Bożej Jasnogórskiej telewizja nadała kazanie ks. Prymasa Kard. S. Wyszyńskiego, by uspokoić ludzi, ale wybór był tendencyjny. Nasz Biskup wydał specjalne orędzie. W Stoczni są odprawiane Msze św.

34. Archiwum Domu Zakonnego 0jców Oblatów w Gdańsku [dalej: ADZ00G], Kronika domu. Gdańsk 1978-1995, s. 234.

35. ADSAK, Kronika Domu, t. 2, s. 85.

36. AKODG, Kronika klasztoru..., b.p.

37. A. Friszke, Rewolucja Solidarności..., s. 43.

38. D. Gucewicz, W cieniu Komitetu..., s. 155.

39. ADZ00G, Kronika domu..., s. 234.

40. AKOCG0, Kronika..., s. 82.

41. Z. Pawłowicz, Kościół i Państwo w PRL 1944-1989, Gdańsk 2004, s. 393.

42. R. Łatka, Polityka władz PRL..., s. 128. 
Nastrój wśród załogi religijny. Chodzimy pod bramę Stoczni popatrzeć i umacniać się w przekonaniu, że nastąpi zwycięstwo, co się tak stało. Władze komunistyczne ustąpiły"43. Na to uroczyste nabożeństwo w intencji ojczyzny zwrócili uwagę również świeccy skupieni przy salezjańskim kościele Najświętszego Serca Pana Jezusa w Gdańsku-Oruni ${ }^{44}$.

Dwa dni później ksiądz Jerzy Błaszczak SAC na wieczornym nabożeństwie odniósł się właśnie do tego zmanipulowanego przez władze w Dzienniku Telewizyjnym i radiu wystąpienia prymasa, mówiąc: „Wszyscy słuchaliśmy dzisiaj w radiu i oglądaliśmy w telewizji wystąpienie prymasa. Jednak nie wszyscy wiedzą, iż w dniu dzisiejszym zarówno księża, biskupi, jak i rozgłośnia watykańska określiła, że transmisje te odbyły się bez jego zezwolenia oraz władz kościelnych. Kazania tego nie transmitowano w całości i nie odzwierciedlało ono prawdziwych intencji prymasa, a ktoś, komu na tym zależało, wybrał sobie dogodne fragmenty i bez zezwolenia duchowieństwa przekazał je przez środki masowego przekazu całej Polsce. Jakże tu więc można mówić o prawdzie i miłości, jeżeli dochodzi do takich sytuacji" ${ }^{\prime \prime}$.

Nie tylko gdańscy zakonnicy byli uczestnikami i świadkami strajku sierpniowego. Na terenie stoczni 27 sierpnia znalazł się ojciec Stanisław Musiał SJ, jezuita, wówczas redaktor katolickiego "Tygodnika Powszechnego". Po przyjeździe do miasta zamieszkał w domu zakonnym przy parafii św. Krzyża w Gdańsku-Wrzeszczu, administrowanej przez jezuitów. Współbracia polecili mu, aby uzyskał przepustkę do stoczni od księdza Jankowskiego. Tak też się stało. Ojciec Musiał SJ rozmawiał z robotnikami i przysłuchiwał się negocjacjom z delegacją rządową. Jak wszyscy bał się, że władze rozbiją strajk, że "wejdą Rosjanie". Po latach wspominał, że atmosfera wypełniona była gorącą dyskusją, podkreślał też znaczenie zespołów eksperckich, bez których strajkujący "nic nie mogliby zrobić [...]. Co chwilę, wychodziły na jaw takie krętactwa strony rządowej - a komuniści przecież dysponowali [...] niesamowitymi możliwościami matactw i nacisków"46. 30 sierpnia 1980 roku strajkowało już 700 tysięcy ludzi w 700 zakładach z 28 województw. Nazajutrz 31 sierpnia 1980 roku podpisano porozumienie. Tego dnia doszło do nieznacznej demokratyzacji, odprężenia, narodzin nowej idei i marzeń. Został zapoczątkowany ruch, który miał zmienić oblicze i system kraju ${ }^{47}$.

Cystersi z Gdańska-Oliwy z poczuciem ulgi odnotowali ten fakt, jak również zgodę władz na "utworzenie, wolnych i niezależnych związków zawodowych Solidarność"48. Oblaci nie kryli swego zadowolenia, że „Rok 1970 dzięki Bogu nie powtórzył się. Ład i porządek, spokój panował w stoczni i innych zakładach"49. Zmartwychwstaniec ksiądz Stefan Duda CR z Wrzeszcza wspominał o dużym poruszeniu i podnieceniu z powodu zakończenia strajku. W domu zakonnym wszyscy śledzili wydarzenia tego dnia w telewizorze: "Obserwujemy to, cała Polska, z rozrzewnieniem, uczucie ulgi i wielkiej nadziei"50. Dominikanin ojciec Ludwik Wiśniewski OP, od lat zaangażowany po stronie

43. AKFG, Kronika, b.p.

44. Archiwum Salezjańskiej Inspektorii Pilskiej, Gdańsk-Orunia, Kronika działalności Pomocników Salezjańskich przy kościele Najśw. Serca Pana Jezusa w Oruni, b.p.

45. Cyt. za: D. Gucewicz, W cieniu Komitetu..., s. 156.

46. Efektem pobytu ojca Musiała SJ był artykuł Msza św. w Stoczni im. Lenina, który w bardzo szybkim czasie od ukazania się zrobił prawdziwą furorę, został przetłumaczony na niemiecki, francuski, włoski, angielski i wiele innych języków. W. Bereś, K. Burnetko, Duchowny niepokorny. Rozmowy z księdzem Stanisławem Musiałem, Warszawa 2006, s. 77-80; S. Musiał, Msza św. w Stoczni im. Lenina, „Tygodnik Powszechny” 1980, nr 37 (31 sierpnia), s. 1-2.

47. A. Friszke, Polska, s. 367-370.

48. AKOCG0, Kronika..., s. 83.

49. ADZ00G, Kronika domu..., s. 234.

50. APNSMG, Kronika - tom III..., b.p. 
opozycji, pisał, że system komunistyczny „potrafił ludzi [...] uśpić. Żyło się w półśnie. Wydawało się nam, że tak już musi być i co najważniejsze należy nauczyć się «manewrować», abyśmy nie zginęli $\mathrm{i}$ aby razem $\mathrm{z}$ nami nie zginęły zasadnicze wartości". Z tego też powodu odwaga, którą odkryli w sobie i wykazali się ludzie w dniach Solidarności, w wypadku niektórych granicząca z bezczelnością, okazała się tak ważna. Dla wielu ludzi razem z Solidarnością przyszło poczucie siły, pozwalające na przeprowadzenie rewolucji, podczas której nie została przelana nawet kropla krwi i nie wybito ani jednej szyby. Solidarność była „Narodowym Zrywem"51.

\section{Zaangażowanie na rzecz Solidarności}

Zawarcie porozumień sierpniowych było bez wątpienia jednym z najważniejszych momentów, które doprowadziły do upadku systemu komunistycznego w Polsce. Powstanie organizacji kontestującej ustrój PRL i chcącej go zmienić postawiło w nowej sytuacji Kościół, który w poprzednim okresie pozostawał jedyną niezależną siłą i starał się nie wspierać żadnego ugrupowania politycznego. Pomoc, której Kościół udzielał Solidarności - jak stwierdził Rafał Łatka - należy traktować jako wyraz troski o dobro wspólne. Kościół odgrywał przede wszystkim rolę doradcy i pośrednika w kontaktach z władzami ${ }^{52}$. Po podpisaniu porozumień zakonnicy generalnie opowiedzieli się za Solidarnością. Utrzymywali też bliskie związki z tym ruchem ${ }^{53}$. Z drugiej strony w kolejnych miesiącach władze rejestrowały wszelkie wzmianki duchownych o Solidarności i gromadziły informacje na temat członków nowego ruchu biorących udział w nabożeństwach w kościele ${ }^{54}$. Władze miały obsesję - pisze historyk ksiądz Dominik Zamiatała CNF, klaretyn - na tle wykorzystywania uroczystości religijnych do antysocjalistycznych wystąpień politycznych. Obawiały się, że duchowieństwo przy organizacji masowych uroczystości będzie dążyć do wszczęcia rozruchów, dlatego agentura otrzymała polecenie, aby ustalić, czy coś takiego jest planowane. SB chciała się zawczasu przygotować55. Zarówno poszczególne klasztory, jak i zakonnicy znaleźli się pod czujną obserwacją Służby Bezpieczeństwa. Nie bez powodu. Ojciec Sławomir Słoma OP w czasie jednego $\mathrm{z}$ wielu spotkań w kościele św. Mikołaja, w lutym 1981 roku, po powrocie delegacji NSZZ "Solidarność" z Lechem Wałęsą na czele $\mathrm{z}$ Watykanu i spotkaniu z papieżem Janem Pawłem II mówił, że jedyną konstruktywną siłą w kraju jest Solidarność, która może wydźwignąć Polskę z kryzysu, do jakiego doprowadziła PZPR. Komunizm jest iluzją i nierealnym ruchem w modelu stworzonym przez ZSRR ${ }^{56}$.

Do kontynuacji działań zakonników na rzecz gdańskiej Solidarności doszło bardzo szybko. Dominikanie prowadzili i wydawali - nielegalnie - przy duszpasterstwie akademickim pismo "Dołek”. Z tego powodu w Wydziale do spraw Wyznań w Gdańsku 3 i 10 grudnia 1980 roku Edward Pobłocki przeprowadził rozmowę ostrzegawczą z ojcem Augustynem Janem Mamulskim 0P, przeorem i proboszczem, oraz z ojcem Sławomirem Słomą OP. Władzy nie podobała się treść pisma. Według sprawozdania po rozmowie zakonnicy zobowiązali się do nieudostępniania kościoła i pomieszczeń klasztoru żadnym organizacjom i ruchom społecznym, do nieorganizowania żadnych wydarzeń poza sakralnymi, jak

51. L. Wiśniewski, Nigdy nie układaj się ze złem, s. 93-97.

52. R. Łatka, Episkopat Polski wobec stosunków państwo - Kościół i rzeczywistości społeczno-politycznej PRL 1970-1989, Warszawa 2019, s. 413.

53. D. Zamiatała, Zakony męskie..., s. 64.

54. R. Eatka, Polityka władz PRL..., s. 159.

55. D. Zamiatała, Zakony męskie..., s. 31.

56. Archiwum Instytutu Pamięci Narodowej, Oddział w Gdańsku [dalej: AIPN Gd.], sygn. 468/1, Meldunki operacyjne z wydz. IV KWMO w Gdańsku za okres od 1.01.81 do 7.09.81, Meldunek operacyjny nr 41 z dnia 4.02.81 od TW „Luty” (30874), k. 48. 
również do uzyskania formalnej zgody na wydawanie pisma. Ojciec Słoma OP odbył podobną rozmowę z biskupem Kaczmarkiem, od 24 wrześni 1980 roku członkiem reaktywowanej Komisji Wspólnej Rządu PRL i Episkopatu Polski, który "ostro skrytykował działalność duszpasterstwa akademickiego 00. Dominikanów" ${ }^{\prime \prime 7}$. To małe pisemko znalazło się również pod obserwacją SB. Jak pisał o tym ojciec Marek Grubka OP, było to o tyle dziwne, że w czasie legalnej działalności Solidarności wiele środowisk wydawało tego typu druki. Bezpieka nie mogła jednak zlokalizować autorów tekstów, redakcji czy miejsca druku. Pomimo nacisków pismo "Dołek" wychodziło nadal ${ }^{58}$. Zakonnika wezwano na przesłuchanie. Według słów Anny Biernat funkcjonariusze mieli wyłożyć przed nim wszystkie numery, co bardzo go ucieszyło. "Macie wszystkie «Dołki» a mnie brakuje kilka numerów" - miał powiedzieć ojciec Słoma ${ }^{59}$. Pod koniec kwietnia 1981 roku SB raportowała, że ośrodek duszpasterski wydaje już 24. numer "Dołka"60. Był to tylko jeden $\mathrm{z}$ wielu przejawów „wrogiej" wobec władz komunistycznych działalności.

Uczestnictwo niektórych księży zakonnych, a takich w Gdańsku było niemało, po stronie opozycji negatywnie oceniała część Episkopatu, uznając je za szkodliwe dla Kościoła. Byli wśród nich biskupi Lech Kaczmarek, Bolesław Pylak ${ }^{61}$ z Lublina i Jerzy
Stroba z Poznania. Niektórzy przełożeni zakonni ulegali presji bezpieki czy władz wyznaniowych i przenosili niewygodnych zakonników do innych placówek $^{62}$. Mniej lub bardziej problem ten dotyczył również Gdańska. Stosunek biskupa Kaczmarka do zakonów był bardzo krytyczny. Według Urzędu do spraw Wyznań w wielu przypadkach kuria toleruje zakonników dlatego, że nie ma odpowiedniej liczby księży diecezjalnych ${ }^{63}$. Również przełożeni zakonni wykazywali krytyczny stosunek do kurii, znając jej negatywne nastawienie do nich ${ }^{64}$. Władze wojewódzkie oraz Urząd do spraw Wyznań wielokrotnie interweniowały $u$ władz zakonu dominikanów w sprawie „szkodliwej dla państwa politycznej działalności niektórych dominikanów w Poznaniu, Krakowie, Gdańsku i Wrocławiu". Mimo wielu tego typu interwencji władze w dalszym ciągu odnotowywały negatywne wobec władz państwowych wystąpienia grup zakonników ${ }^{65}$.

21 listopada 1980 roku w kościele Dominikanów ojciec Stanisław Słoma OP zaprosił do duszpasterstwa akademickiego ("Górka”) Annę Walentynowicz. Na spotkaniu omawiano między innymi plany wydawania tygodnika "Solidarność", który miał zacząć wychodzić 1 grudnia, a także starania o codzienną dziesięciominutową audycję w telewizji. Według agenta Służby Bezpieczeństwa TW „Luty” (Marian Puzdrowski), studenta UG, na

57. Archiwum Państwowe w Gdańsku [dalej: APG], Wydział do Spraw Wyznań Wojewódzkiej Rady Narodowej w Gdańsku [dalej: WdSW], sygn. 2375/1790. Urząd Wojewódzki Wydział do Spraw Wyznań do Urzędu do Spraw Wyznań w Warszawie, 15 grudnia 1980 r., k. 283; S. Bogdanowicz, Kościół gdański..., s. 368. Problematykę zarówno reaktywacji Komisji Wspólnej, jak i jej działalności w latach osiemdziesiątych, a także w okresie, którego dotyczy niniejszy tekst, opisał K. Michalski, Działalność Komisji Wspólnej przedstawicieli Rządu PRL i Episkopatu Polski 1980-1989, Warszawa 2012, s. 73-104.

58. M. Grubka, Działania władz..., s. 277.

59. Ibidem.

60. AIPN Gd., sygn. 468/1, Meldunek operacyjny nr 189 z dnia 28.04.81 od TW „Luty” (30874), k. 215.

61. Bolesław Pylak był werbowany przez SB dwukrotnie. Po raz pierwszy współpracował w latach 1959-1965 jako TW „Teolog”, następnie od 1971 roku jako TW „Bolesław”. R. Łatka, Episkopat Polski..., s. 305.

62. D. Zamiatała, Zakony męskie..., s. 63.

63. Archiwum Akt Nowych [dalej: AAN], sygn. 133/18, Urząd Wojewódzki w Gdańsku do Urzędu do Spraw Wyznań w Warszawie, 29 sierpnia 1980 r., k. 110.

64. Największe utarczki z kurią mieli pallotyni, dominikanie, jezuici oraz zmartwychwstańcy. Głównie dotyczyły one obsady personalnej oraz polityki erekcji parafii; AAN, sygn.133/18, Urząd Wojewódzki w Gdańsku do Urzędu do Spraw Wyznań w Warszawie, 29 sierpnia 1980 r., k. 110-111.

65. D. Zamiatała, Zakony męskie..., s. 76. 
kolejnym spotkaniu miał być obecny Lech Wałęsa, dla którego studenci kupili rower ze składek ${ }^{66}$. Pod koniec 1980 roku szczególnie podniosły charakter, będący wyrazem pozornego uspokojenia, przybrało odsłonięcie i poświęcenie 16 grudnia 1980 roku pomnika Poległych Stoczniowców 1970 w Gdańsku w dziesiątą rocznicę wydarzeń ${ }^{67}$. Dom zakonny pallotynów przy kościele św. Elżbiety zaangażowano w obchody rocznicy oraz w uroczystości odsłonięcia pomników w Gdańsku i Gdyni. W tracie uroczystości w kościele zorganizowano posługę duszpasterską dla rodzin poległych stoczniowców oraz specjalny punkt informacyjny zapewniający im opiekę i kwaterunek. W maju 1981 roku na ręce księdza Błaszczaka SAC Komitet Społeczny Budowy Pomnika "Poległych Stoczniowców 1970" przysłał pismo z podziękowaniami oraz album podpisany przez Lecha Wałęsę ${ }^{68}$. W prace i rozmowy z Lechem Wałęsą był również zaangażowany ksiądz Alojzy Orszulik SAC, pallotyn, od listopada 1980 roku członek i sekretarz Komisji Wspólnej Przedstawicieli Episkopatu Polski i Rządu PRL, łącznik między episkopatem a przywódcą Solidarności ${ }^{69}$. Oblaci do pomocy w organizacji obchodów oddelegowali ojca Edmunda Wróbla OMI. W samej uroczystości brał udział superior domu zakonnego ojciec Władysław Hirsz OMI oraz delegat prowincjała ojciec Edmund Stefański $\mathrm{MMI}^{70}$. Wzniesienie monumentu ku czci poległych stoczniowców gwardian franciszkanów konwentualnych z Gdańska opisał następująco: „imponujący pomnik jest oskarżeniem rządzącej partii ateistycznej i zwycięstwem polskiego robotnika.
Czołową postacią [...] jest Lech Wałęsa, człowiek nie wstydzący się swej wiary i noszący na szyi różaniec, który przekazał jeden z ojców kapucynów. Rozpoczął się w Polsce ruch odnowy. Najbardziej jest potrzebna odnowa moralna narodu"71.

Na rzecz Solidarności wciąż zaangażowani byli pallotyni z obu gdańskich domów. Ksiądz Jerzy Błaszczak SAC oraz ksiądz Stefan Potoniec SAC z kościoła św. Elżbiety włączyli się w pomoc strajkującym od 7 listopada 1980 roku pracownikom administracji publicznej, oświaty, służby zdrowia i kultury. Ksiądz Błaszczak SAC 16 listopada odprawił dla 150-200 osób mszę w gmachu Urzędu Wojewódzkiego. Jego współbrat, ksiądz Eugeniusz Klimiński SAC, odprawił 11 listopada mszę dla studentów Akademii Medycznej, strajkujących solidarnie od 8 listopada ${ }^{72}$. Zakonnicy pospieszyli z posługą do strajkujących studentów (Niezależnego Zrzeszenia Studentów) również w trudnym okresie stanu wojennego, w grudniu 1981 roku. Duszpasterze akademiccy codziennie o godzinie 19.00 odprawiali msze uczelniane dla strajkujących studentów: ojciec Słoma OP na Wydziale Ekonomiki Transportu UG w Sopocie i w Wyższej Szkole Sztuk Plastycznych, ojciec Hubert Fabian Lipiński OFMConv. na Wydziale Humanistycznym UG. W kronice zapisano, że "0. Hubert codziennie odwiedza młodzież akademicką na Wydziale Humanistyki, która włączyła się do ogólnopolskiego strajku akademickiego. Tam o. Hubert odprawia codziennie Mszę św., wygłosił też konferencję". Z kolei pallotyn ksiądz Eugeniusz Klimiński SAC był obecny wśród strajkujących przyszłych medyków ${ }^{73}$.

66. Informacja od TW ps. „Luty” dotycząca spotkania Anny Walentynowicz z młodzieżą w kościele św. Mikołaja w Gdańsku, [w:] Kryptonim "Klan". Służba Bezpieczeństwa wobec NSZZ "Solidarność" w Gdańsku”, t. 1: wrzesień 1980 - wrzesień 1981, wstęp

S. Cenckiewicz, wybór i oprac. M. Kruk, R. Żydonik, współpraca S. Cenckiewicz, Warszawa-Gdańsk 2012, s. 263-265.

67. Z. Pawłowicz, Kościół i Państwo w PRL..., s. 394.

68. ADSAK, Kronika domu, t. 2, s. 111; D. Gucewicz, W cieniu Komitetu..., s. 159.

69. Meldunek naczelnika Wydziału IV KW MO w Gdańsku mjr. Ryszarda Berdysa do naczelnika Wydziału IV Departamentu IV MSW, [w:] Kryptonim "Klan", s. 288-292.

70. ADZ00G, Kronika domu..., s. 239-240.

71. AKFG, Kronika, b.p.

72. ADSAK, Kronika domu, t. 2, s. 91; D. Gucewicz, W cieniu Komitetu..., s. 156-157.

73. AKFG, Kronika, b.p; AIPN Gd, sygn. 468/4/2, Meldunki operacyjne z wydz. IV KWM0 w Gdańsku za okres od 7.09 .81 do 31.12.81, Meldunek operacyjny nr 690 z 9.12.1981, k. 381. 
Ksiądz Klimiński SAC oraz ksiądz Dutkiewicz SAC organizowali spotkania, zarówno w świątyni, jak i w salach duszpasterskich. Byli tam obecni: Jerzy Turowicz, Zbigniew Herbert, ksiądz Janusz Pasierb, który przyjeżdżał przez cały rok z wykładami „Na styku kultury chrześcijańskiej i subkultury współczesnej", Lech Wałęsa, Anna Walentynowicz, ksiądz Józef Tischner, Jacek Kuroń, Lech Kaczyński, Tadeusz Mazowiecki. Znani aktorzy recytowali poezję księdza Jana Twardowskiego, Andrzeja Jawienia (Karola Wojtyły), Artura Międzyrzeckiego, Tadeusza Staicha. Zespół aktorów Teatru Wybrzeże wystawił Hioba i Przed sklepem jubilera Karola Wojtyły. Organizowane były prezentacje filmów, spotkania z aktorami, tygodnie kultury chrześcijańskiej czy tydzień poświęcony polskiemu fenomenowi budów sakralnych, a także dyskusje z dziennikarzem Stefanem Bratkowskim. Z punktu widzenia duszpasterzy ważne było to, że na spotkania przychodziła młodzież studencka z wielu uczelni Gdańska i Gdyni ${ }^{74}$. Współuczestnictwo środowisk twórczych było konsekwencją działań podjętych jeszcze w marcu 1980 roku. Decyzją prymasa Polski powołano duszpasterza środowisk twórczych w Warszawie, którym został ksiądz Wiesław Niewęgłowski. Tuż po powstaniu Solidarności założono Komitet Porozumiewawczy Środowisk Twórczych i Naukowych ${ }^{75}$. To pole działalności ksiądz Klimiński SAC podsumował następująco: „ten przekrój, na podstawie jednego choćby, przecież nie największego ośrodka duszpasterskiego w Gdańsku, daje obraz wielkiej aktywności środowisk, w jakich żył i działał Kościół Gdański tamtego czasu"76.
25 stycznia 1981 roku w kościele św. Mikołaja ojciec Stanisław Słoma OP odprawił mszę dla około 150 studentów, ustosunkowując się w kazaniu do aktualnej sytuacji społeczno-politycznej w Polsce. Wymienił postulaty nadal niezrealizowane przez rząd PRL (wolne soboty, dostęp do środków masowego przekazu, wyrównanie zasiłków rodzinnych i płatny trzyletni urlop macierzyński). Dominikanin mówit, że domaganie się przez Solidarność ich realizacji jest słuszne i wymaga protestu, jakim jest strajk $^{77}$. Zakonnicy wyrażali jednocześnie zadowolenie $\mathrm{z}$ tego, że papież $\mathrm{w}$ czasie wizyty delegacji Solidarności z Lechem Wałęsą na czele w Rzymie (13-15 stycznia 1981) popark nowy demokratyczny ruch społeczny, działający legalnie w Polsce ${ }^{78}$. Dominikanie 22 lutego 1981 roku zorganizowali kolejne już spotkanie z Anną Walentynowicz, która dzieliła się z zebranymi (około 150 osób, w tym 50 studentów) refleksjami z pobytu delegacji Solidarności w Rzymie. Zapewniała, że Solidarność „,walczyła i nadal będzie walczyć o uwolnienie więźniów politycznych w Polsce". Mówiła również o tym, że dostęp działaczy związku do radia i telewizji miał być gwarantem prawdziwych informacji, pozbawionych kłamstw ${ }^{79}$.

Zakonnicy gdańscy zaangażowali się również w organizujący się w Gdańsku Klub Inteligencji Katolickiej (KIK). Przy kościele Zmartwychwstańców we Wrzeszczu (gdzie prowadzili duszpasterstwo akademickie) już w połowie lata 1980 roku zaczęło gromadzić się grono młodych ludzi, działaczy i członków KIK. Wśród nich byli: inicjator

74. Ksiądz Eugeniusz Dutkiewicz..., s. 64.

75. J. Żaryn, Kultura niezależna w Kościele katolickim w Polsce 1981-1989. Szkic do portretu, [w:] Kościół i kultura w latach osiemdziesiątych XX wieku. Doświadczenia warszawskie, pod red. W.A. Niewęgłowskiego, współpraca M. Romańska, KatowiceWarszawa 2014, s. 24.

76. E. Klimiński, Do niego należy czas, s. 87.

77. AIPN Gd., sygn. 468/1, Meldunki Meldunek operacyjny nr 29 z dnia 28.01.81 od TW "Rafał” (22514), k. 34. Według raportu SB z początku 1981 roku zmartwychwstańcy obawiali się wprowadzenia wszystkich sobót jako dni wolnych, "ponieważ wyjazdy już w piątek, wielu ludzi na wypoczynek poza miasto wpłyną na zmniejszenie się frekwencji na niedzielnych nabożeństwach". AIPN Gd., sygn. 468/1, Meldunki operacyjne z wydz. IV KWM0 w Gdańsku za okres od 1.01.81 do 7.09.81, Meldunek operacyjny nr 34 z dnia 30.01.81. od TW „Rafał” (22514), k. 41.

78. AIPN Gd., sygn. 468/1, Meldunek operacyjny nr 34 z dnia 30.01.81. od TW "Rafal” (22514), k. 41.

79. AIPN Gd, sygn. 468/1, Meldunek operacyjny nr 76 z dnia 5.03.81 od TW "Luty" (30874), k. 88-89. 
Stefan Gomowski, Tadeusz Bień (obaj uczestnicy wydarzeń Marca '68) i Jerzy Kowalczyk (uczestnik Grudnia '70), a z czasem dołączyli do nich również Andrzej Dembiński, Jerzy Grzywacz oraz Piotr Nowina-Konopka. W okresie Solidarności niemal wszystkie wymienione osoby aktywnie włączyły się w tworzenie nowego związku w swoich zakładach pracy czy też na uczelni ${ }^{80}$. Asystentem kościelnym KIK, po księdzu Jerzym Zarembie, został mianowany nieformalnie przez biskupa - pallotyn ksiądz Jerzy Błaszczak SAC, kontynuujący dobre relacje pallotynów z inteligencją ${ }^{81} .16$ stycznia 1981 roku odbył się tradycyjny opłatek inteligencji zrzeszonej w KIK. Podczas uroczystej mszy w kaplicy Królewskiej ksiądz Eugeniusz Klimiński SAC wygłosił mowę, w której powiedział: „obecnie powstała nadzieja dla Polaków, dzięki spontanicznemu zrzeszeniu się $\mathrm{w}$ «Solidarności» robotników, chłopów i inteligencji"82. Od 25 do 29 kwietnia 1981 roku KIK wraz z Akademickim Kręgiem Literackim "Górka" przy kościele św. Mikołaja oraz miesięcznikiem „W Drodze” współorganizował Dni Kultury Chrześcijańskiej, w czasie których mszę odprawił biskup Kaczmarek (wygłosił też konferencję). Nastąpił żywy rozwój klubu oraz jego sekcji ${ }^{3}$. 24 maja 1981 roku z inicjatywy KIK w kaplicy Królewskiej zorganizowano spotkanie pod hasłem "Świadectwo wiary - Sierpień '80", w czasie którego do zebranych mówili między innymi ksiądz Jankowski oraz pallotyni ksiądz Błaszczak SAC i ksiądz Klimiński SAC ${ }^{84}$.

Ze środowiskami kultury i filmu współpracowali przede wszystkim dominikanie. 22 marca 1981 roku w kościele św. Mikołaja otwarto wystawę Zapis 80, poświęconą strajkom sierpniowym. 0twarcia wystawy dokonała Anna Walentynowicz, zaproszona przez ojca Słomę OP. Następnie aktorzy Teatru Wybrzeże należący do Solidarności recytowali poezję ${ }^{85}$. Na wystawie I Zjazd Delegatów NSZZ Solidarność, zorganizowanej w pomieszczeniach duszpasterstwa akademickiego, wystawiono kilkadziesiąt fotogramów z obrad zjazdu ${ }^{86}$. Z kolei 6 kwietnia 1981 roku na "Górce" zorganizowano projekcję filmu dokumentalnego Robotnicy 80. Obecna na nim była grupa około 50 osób. Według doniesienia TW „Luty” jeden z trójki reżyserów, Andrzej Chodakowski, krytykował kierownictwo telewizji i filmu za niedopuszczenie na ekrany ciekawych filmów, stwierdzając, że woleli kręcić "wizytę Gierka u Breżniewa czy obrady ZSMP niż film «Robotnicy $80 » " 87$.

W sprawie zaangażowania się zakonników na rzecz Solidarności władze wiele razy pisały monity do prymasa, biskupów, Sekretariatu Episkopatu Polski i Konferencji Wyższych Przełożonych Zakonów Męskich. Oskarżano zakony i poszczególnych zakonników o przechowywanie na terenie domów zakonnych nielegalnej literatury, ulotek, wykorzystywanie pomieszczeń zakonnych do celów pozareligijnych, jak również o organizację spotkań z aktywistami Solidarności i innymi działaczami antypaństwowymi. W ocenie władz w Trójmieście najbardziej politycznie zaangażowani byli dominikanie i pallotyni w Gdańsku oraz redemptoryści i franciszkanie w Gdyni ${ }^{88}$. W wypadku Gdańska można przyznać władzom rację.

80. D. Gucewicz, "Przestrzeń wolności” w Trójmieście. Dzieje gdańskiego Klubu Inteligencji Katolickiej (do 1990 r.), [w:] Kluby Inteligencji Katolickiej jako przestrzeń działań niezależnych w latach osiemdziesiątych XX wieku, pod red. K. Białeckiego, Warszawa-Poznań 2014, s. 264-265.

81. Ibidem, s. 268.

82. Ibidem, s. 270.

83. AKODG, Kronika klasztoru..., b.p.

84. D. Gucewicz, "Przestrzeń wolności"..., s. 272-273.

85. AIPN Gd., sygn. 468/1, Meldunek operacyjny nr 114 z dnia 25.03.81 od TW „Rafał” (22514), k. 137.

86. AIPN Gd 468/4/2, Meldunki operacyjne z wydz. IV KWM0 w Gdańsku za okres od 7.09.81 do 31.12.81, Meldunek operacyjny nr 644 z 23.11.1981, s. 335.

87. AIPN Gd, sygn. 468/1, Meldunek operacyjny nr 151 z dnia 1.04.81 od TW „Luty” (30874), k. 177.

88. D. Zamiatała, Zakony męskie..., s. 77. 
1 kwietnia 1981 roku w ramach rekolekcji wielkopostnych u dominikanów odbyło się spotkanie z ojcem Wiśniewskim 0P, który poruszał problem postawy chrześcijanina wobec niesprawiedliwości i zła. Mówiąc o rzeczywistości społeczno-politycznej, oceniał nieużywanie przez Solidarność siły jako drogę właściwą. Cieszył się, że negocjacje nie doprowadziły do użycia przemocy. Spotkanie zostało powtórzone 2 kwietnia $1981 \mathrm{roku}^{89}$. Na Wielkanoc 1981 roku gdańscy franciszkanie przygotowali też specjalną oprawę Grobu Pańskiego z symbolem rąk okalanych kajdanami („akcent mocno na czasie”, jak notował kronikarz) ${ }^{90}$. Kościół św. Elżbiety decyzją biskupa Kaczmarka stał się miejscem, z którego rozpoczęto nadawanie mszy przez radio. W eter po raz pierwszy poszła "dla ludzi morza" 3 maja 1981 roku, a odprawił ją wikariusz generalny diecezji ksiądz Bernard Polzin. Aż do wprowadzenia stanu wojennego msze odbywały się w niedzielę o godzinie 15.00 oraz 23.00 (dla ludzi na morzach i oceanach). Stroną techniczną zajmowali się pracownicy stacji brzegowej Gdynia-Radio ${ }^{91}$.

Minister spraw wewnętrznych Mirosław Milewski podczas spotkania $\mathrm{z}$ warszawskimi rezydentami służb specjalnych krajów bloku radzieckiego powiedział: "Między Kościołem i KOR toczy się teraz walka, kto z nich będzie miał większy wpływ i lepszą pozycję w "Solidarności»". Tę walkę - jak przyznawał - "wspieramy”, "zaostrzamy” i "przedłużamy"92. Milewski nie mówił tego bezpodstawnie. Zakonnicy nie byli wolni od uprzedzeń i sympatii, również wobec środowiska opozycji demokratycznej, a SB dbała oto, żeby zapewnienia ministra były realne. Według jednego $\mathrm{z}$ wielu raportów na ten temat oblaci z kościoła św. Józefa uważali, że władze powinny zdecydowanie przystąpić do ograniczenia i likwidacji takich ugrupowań jak KPN i RMP, a wobec strajkujących studentów zastosować radykalne, a nawet drastyczne środki, takie jak czasowe zamknięcie wszystkich uczelni i przeprowadzenie weryfikacji ${ }^{93}$. Jezuita ojciec Bronisław Sroka SJ, przemawiając w kościele św. Bartłomieja w Gdańsku, krytykował KOR, w którego działalność był kiedyś zaangażowany. Zerwał z tą organizacją, kierując się tym, że „KOR jest kierowany przez Żydów, bezbożników i ateistów". Mówił, że podjął działalność tylko na rzecz Solidarności, i uważał, że tylko ten ruch ma przyszłość. Jego współbracia w prywatnych rozmowach zastanawiali się, dlaczego SB nie aresztowała kierownictwa KOR-u, tak jak postąpiono wobec KPN. Snuli bardzo różne domysły, według których "KOR jest kierowany przez Żydów cieszących się poparciem finansjery żydowskiej Zachodu. Dopóki kraj nasz będzie zadłużony KOR będzie działał" ${ }^{\prime 4}$. Tego typu wypowiedzi niestety wpisywały się w politykę władz komunistycznych.

Bardzo krytyczny stosunek do ustroju oraz do władz wykazywał oblat ojciec Szczepan Brzezina OMI, który według raportu TW "Luty" 1 marca 1981 roku o godzinie 12.00 w kościele św. Józefa w kazaniu zatytułowanym Nie można służyć dwom panom powiedział: „mamy wstręt do Polaków, którzy pełnili funkcję kapo w obozach, bijąc i mordując niewinnych więźniów. Mam także wstręt do ludzi z UB, którzy zaraz po wojnie również kopali i bili Polaków" ${ }^{\prime \prime 5}$. Jego słowa odnosiły się do aktualnej sytuacji politycznej. Według niego należało się opowiedzieć po dobrej stronie - Solidarności, lub tej drugiej - władz komunistycznych. 9 kwietnia 1981 roku w kościele św. Mikołaja mszę poświęconą ofiarom Katynia odprawił ksiądz Ryszard Szczygieł SAC, pallotyn z Otwocka, który modlił się o zamor-

89. AIPN Gd, sygn. 468/1, Meldunek operacyjny nr 191 z dnia 6.04.81 od TW "Luty" (30874), k. 218.

90. AKFG, Kronika, b.p.

91. ADSAK, Kronika domu, t. 2, s. 105.

92. A. Dudek, PRL bez makijażu, Kraków 2008, s. 153.

93. AIPN Gd, sygn. 468/1, Meldunek operacyjny nr 53 z dnia 17.02.81 od TW "Alek" (6939), k. 60.

94. AIPN Gd, sygn. 468/1, Meldunek operacyjny nr $111 \mathrm{z}$ dnia 25.03.81 od TW "Tadeusz" (17390), k. 133-134.

95. AIPN Gd., sygn. 468/1, Meldunek operacyjny nr 75 z dnia 4.03 .81 od TW „Artur" (13089), k. 98. 
dowanych, przebaczenie i miłosierdzie, a przede wszystkim o pamięć. Po zakończeniu mszy, o godzinie 19.15 została odprawiona nowenna do Matki Bożej Lwowskiej. W bocznej nawie położono wieniec z szarfą z napisem "Ofiarom Katynia - Konfederacja Polski Niepodległej". W wieniec wetknięto biało-czerwone chorągwie, a na każdej z nich widniała nazwa: "Ostaszków, Starobielsk, Kozielec"96. 18 czerwca 1981 roku podczas procesji z kościoła jezuitów we Wrzeszczu (św. Krzyża) ojciec Tadeusz Pawlicki SJ apelował do wiernych o modlitwę, aby nie zabrakło w Polsce kapłanów. Stwierdził również, nawiązując do sytuacji katolików w krajach bloku wschodniego, głównie w ZSRR: „wcale nie na dalekim wschodzie, lecz całkiem blisko ludzie modlą się sami, bez udziału kapłanów i z tego powodu nie mają możliwości przyjmowania sakramentu [...] $]^{\prime 97}$. Aparat bezpieczeństwa był zainteresowany poglądami politycznymi zakonników, zwłaszcza jeśli dotyczyły Solidarności.

26 lipca 1981 roku podczas obiadu po odpuście w domu zakonnym kapucynów przy kościele św. Jakuba w Gdańsku ksiądz Henryk Jankowski dzielił się swoimi wrażeniami z pobytu delegacji Solidarności u prymasa Józefa Glempa. Proboszcz św. Brygidy sugerował księżom parafii i zakonnym, aby w rozmowach z parafianami wyrażali swoje poparcie dla Wałęsy ${ }^{98}$. Również reformaci z Nowego Portu włączyli się w aktywność na rzecz Solidarności. 0jciec Dominik Kabattek 30 sierpnia 1980 roku został zaproszony przez Komisję Zakładową NSZZ "Solidarność" Portu Gdańskiego na uroczystości odbywające się na Westerplatte. Chodziło o odbywającą się o godzinie 10.30 Pierwszą Rocznicę Sierpnia 1980 roku. Mszę odprawił biskup Lech Kaczmarek, podczas której nad grobami poległych ustawiono krzyż oraz poświęcono sztandar związkowy NSZZ „Solidarność" Portu Gdańskiego ${ }^{99}$.
We wrześniu 1981 roku w kościele Jezuitów we Wrzeszczu podczas nabożeństwa kazanie wygłosił jezuita, nawiązując w nim do wydarzeń strajków sierpniowych. Stwierdził, że społeczeństwo upomniało się wówczas o prawdę: „Przez 38 lat ze środków masowego przekazu płynęło kłamstwo i dzięki temu młodzież zapomniała o Bogu. Nie jest ona obecnie ani komunistyczna ani katolicka. [...] 0kupant niszczył ten symbol zarówno po powstaniu styczniowym, w czasie okupacji niszczono oraz niszczono go też w ciągu ostatnich 35 lat". W obecności trzydziestoosobowej grupy członków Solidarności Portu Północnego w Gdańsku zakonnik powiedział, że tamte trudne czasy więcej się nie powtórzą, ponieważ Solidarność będzie stała na straży zdobyczy Sierpnia i zadba o powrót narodu do wiary ojców ${ }^{100}$.

Aktualna sytuacja społeczno-polityczna w kraju wzbudzała zaniepokojenie wśród gdańskich zmartwychwstańców. W raporcie SB zanotowano: „Wierzą w to, że pomimo wzrostu napięcia rząd porozumie się $\mathrm{z}$ «S» w imię dobra narodu. Ostatnią decyzję o powołaniu wojskowych grup operacyjnych uważają za manewr mający zastraszyć «S». W tym pociągnięciu dostrzegają także pewne ryzyko, gdyż rządowi poza wojskiem nie pozostało innych atutów i użyć w jego imieniu ostateczności". Jednak za sytuację polityczną zakonnicy winili również stronę solidarnościową. Mieli jednak otrzymać zalecenie z prowincji, aby w kazaniach nie poruszać drażliwych tematów natury społeczno-politycznej i niepotrzebnie nie zaostrzać nastrojów ${ }^{101}$. Nadzwyczajna sytuacja w kraju, która zapanowała pod koniec drugiej połowy 1981 roku, wywołała wśród gdańskich pallotynów ożywione dyskusje. 0 ile wierzyć raportom SB, zakonnicy, tak bardzo zaangażowani na rzecz Solidarności, oceniali sytu-

96. AIPN Gd, sygn. 468/1, Meldunek operacyjny nr 190 z dnia 29.04.81 od TW "Luty" (30874), k. 219.

97. AIPN Gd, sygn. 468/2, Meldunek operacyjny nr $267 \mathrm{z}$ dnia 22.06.81, k. 316.

98. AIPN Gd, sygn. 468/2, Meldunek operacyjny nr 349 z dnia 12.08.81 od TW "Józek" (3646), k. 406.

99. AKRNP, Kronika 01, s. 478; B. Brzuszek, O. Dominik Norbert Kabattek OFM, s. 98; W. Nocny, Nowy Port, s. 164.

100. AIPN Gd, sygn. 468/4/1, Dok. Nr 8, miejscowy Jezuita, k. 14.

101. AIPN Gd 468/4/2, Meldunek operacyjny nr 611 z 6.11.1981, s. 296. 
ację na zimno. Uważali, że rząd i partia nie mają dużego zaufania społecznego, ponieważ nie widać poprawy gospodarczej i społecznej, brakowało im również konsekwencji w działaniu i śmiałych, skutecznych reform. Pallotyni uważali, że terenowe grupy wojskowe "na dłuższą metę powinny zastępować szczeble administracji państwowej". Odnosili się również do spotkania generała Jaruzelskiego z prymasem Glempem i Lechem Wałęsą. Podkreślali trzeźwość umysłu szefa rządu, "utworzenie zaś frontu porozumienia narodowego pozwala przewidywać bliski już koniec kryzysu społecznego, politycznego i gospodarczego kraju"102. Dyskusje te, dość sceptyczne również wobec ruchu solidarnościowego, mniej dziwią, gdy weźmie się pod uwagę, że od sierpnia 1980 do listopada 1981 roku poparcie spoŁeczne dla Solidarności spadło z 74 do 58 procent, a zaufanie do rządu wzrosło z 30 do 51 procent. Proces ten miał wiele przyczyn, ale jedną z najważniejszych była wojna psychologiczna prowadzona przez kierownictwo PZPR ze związkiem za pomocą mediów oraz tajnych służb ${ }^{103}$.

\section{Reakcje na wprowadzenie stanu wojennego}

13 grudnia 1981 roku generał Wojciech Jaruzelski ogłosił wprowadzenie stanu wojennego i powołanie Wojskowej Rady Ocalenia Narodowego. Zawieszono działalność większości organizacji i stowarzyszeń, wprowadzono godzinę milicyjną, zakazano strajków, manifestacji i zgromadzeń. Co najważniejsze jednak, zawieszono działalność Solidarności, internowano kilka tysięcy działaczy związku, których rozmieszczono w kilkudziesięciu ośrodkach odosobnienia ${ }^{104}$.
Do tych wydarzeń, już w dniu wprowadzenia stanu wojennego, odnosili się gdańscy zakonnicy, zaangażowani w powstanie i działalność Solidarności. Ksiądz Klimiński SAC pisał: „Trudne były nasze przedpołudniowe Msze św. niedzielne. I przerażenie i smutek i te nasze "Boże coś Polskę»" ${ }^{105}$. Aby upamiętnić te wydarzenia, od 1982 do 1989 roku w kościele Reformatów w Nowym Porcie 13 grudnia odbywały się rocznicowe msze. Co ciekawe, u reformatów odbywała się również msza w rocznicę zakończenia strajków sierpniowych ${ }^{106}$. Cystersi 13 grudnia 1981 roku zapisali, że "naród pogrążył się w wielkim smutku", a narzucone ograniczenia odbierali jako szykany ${ }^{107}$.

Dominikanin ojciec Sławomir Słoma podczas demonstracji ulicznej przy budynku Polskiej Akademii Nauk, stojąc naprzeciwko kordonu ZOM0, odprawił „mszę na dłoniach”, za co otrzymał reprymendę od biskupa Kaczmarka ${ }^{108}$. Nie wspominał dobrze tej rozmowy: „Donieśli biskupowi, że ja poszedłem odprawić tam Mszę świętą i nawet nie wiedział jak ja się nazywam, skąd ja jestem, jakiś Słoma, ksiądz Słoma. [...] To było moje pierwsze spotkanie z biskupem, i ostatnie. [...] Doświadczenie niemiłe. Pomyślałem, że może porozmawia ze mną jak z człowiekiem, a on - niestety - było takie ubeckie spotkanie. Bardziej zapamiętałem spotkanie $\mathrm{z}$ biskupem, jak te spotkania z zomowcami"109.

W sąsiedztwie domów pallotynów przy ulicy Elżbietańskiej oraz Marii Curie-Skłodowskiej rozgrywały się dramatyczne sceny pierwszych godzin i dni stanu wojennego: "Granaty z dymem łzawiącym, kordony ZOM0, czołgi i transportery opancerzone, to był prawie codzienny widok z klasztoru". Chwilę

102. AIPN Gd, sygn. 468/4/2, Meldunek operacyjny mjr. mgr. Jana Sosnowskiego nr 752 z 15.12 .81 r., k. 443.

103. A. Dudek, PRL..., s. 151-152.

104. A. Dudek, R. Gryz, Komuniści i Kościół..., s. 373; A. Paczkowski, Wojna polsko-jaruzelska. Stan wojenny w Polsce 13 XII 1981 - 22 VII 1983, Warszawa 2006, s. 55-267.

105. E. Klimiński, Do niego należy czas, s. 92.

106. AKRNP, Kronika 01, s. 553.

107. AKOCG0, Kronika..., s. 89.

108. J. Puciłowski, Portrety imienne i bezimienne. Polscy dominikanie a bezpieka 1945-1989, Kraków 2017, s. 165.

109. M. Grubka, Działania władz..., s. 278. 
później w kierunku Akademii Medycznej we Wrzeszczu ruszyły karetki. Jacek Starościak, opozycjonista uczęszczający do kaplicy Matki Bożej Częstochowskiej, wspominał te dni: „Nasz kościółek od pierwszych dni stanu wojennego zapisywał szczególną i piękną kartę. Wielką rolę należy przypisać świetnej grupie kapłanów o głębokiej religijnej i obywatelskiej formacji [...]. Byli to ks. Eugeniusz Klimiński, ks. Jerzy Firczyk i oczywiście ks. Eugeniusz Dutkiewicz". Ksiądz Dutkiewicz SAC miał być podobno jednym z pierwszych, którzy w Gdańsku zajęli się pomocą dla rodzin internowanych. W domu wraz ze swoimi najbliższymi współpracownikami zaczął kompletować sprzęt poligraficzny oraz tworzyć nielegalną radiostację i łączność telefoniczną dla Solidarności ${ }^{110}$. W domu przy św. Elżbiecie przez kilka dni od wprowadzenia stanu wojennego ukrywał się Zbigniew Bujak. Przemycono go z Bazyliki Mariackiej. Z domu zakonnego został następnie przewieziony w przebraniu, przy pomocy zaprzyjaźnionych aktorów z Teatru Wybrzeże, do szpitala wojewódzkiego. Tam ukrywała go Maria Wyszomirska. Co ciekawe, do Gdańska właśnie 13 grudnia przybył ksiądz Jan Pałyga SAC, który wspominał, że nie zauważył wprowadzenia stanu wojennego. 0dbył w Gdańsku kilka rozmów ze Zbigniewem Bujakiem, który według niego „bał się [...]; zaniepokojony formacją polityczną liderów «S»"111.

Ojciec Mieczysław Seroczyński OFMConv., franciszkanin z kościoła Świętej Trójcy, zapisał: "Generał Jaruzelski wraz z Wojskową Radą Ocalenia Narodowego chce wprowadzić porządek wymierzony przeciw «Solidarności». Społeczeństwo z niepokojem przyjęło tę decyzję. Czy spokój będzie? Nie długo trzeba było czekać, bo 16 grudnia przed pomnikiem i przy dworcu Głównym miały miejsce zajścia między demonstrującymi a Milicją, która gazami łzawiącymi rozpędzała tłum. Wiele osób było rannych. Były liczne aresztowania"112. Na represje pierwszych dni zwracali również uwagę dominikanie, którzy pisali, że od 16 do 17 grudnia ZOM0 wraz z wojskiem zajmowały zakłady pracy, dochodziło też do utarczek ulicznych. Ustawiono posterunki pod pomnikiem Poległych Stoczniowców. 16 grudnia władze nie pozwoliły na odprawienie mszy pod pomnikiem, mimo że zebrało się bardzo dużo ludzi. W późniejszych starciach ulicznych aresztowano 300 osób, a trzy zginęły od kul milicjantów. Przesłuchani przez SB zostali również przeor oraz inni zakonnicy z klasztoru, jak również znane im siostry zakonne $^{113}$. Reformaci pisali w podobnym tonie. 13 grudnia miał być dniem spokojnym. Wszyscy byli sparaliżowani strachem, nie wiedzieli, co się dzieje, "ale już od poniedziałku zaczęły się dziać straszliwe sceny, strajki okupacyjne w zakładach pracy, uliczne demonstracje. [...] Polska została odcięta od reszty świata, co więcej miejscowości od miejscowości tuż przed Bożym Narodzeniem. Przed stocznią Gdańska silne kordony milicji i wojska"114.

Już 19 grudnia 1981 roku SB przeprowadziła rozmowę dyscyplinującą z księdzem Janem Mendelakiem SJ, jezuitą, przełożonym domu zakonnego przy kościele św. Bartłomieja. Tematem rozmowy były negatywne polityczne kazania wygłaszane przez księży. Jezuita odpowiedział, że ocenia działania społeczeństwa sprzeciwiającego się stanowi wojennemu pozytywnie. Sam był w czasie demonstracji na ulicy i niósł pomoc poszkodowanym. Uważał również, że wbrew temu, co piszą i mówią rządowe media, Solidarność nie chciała przejąć władzy. Jednocześnie obiecał, że „w kazaniach nie będzie poruszał tematów, które powodowałyby niepokoje społeczne. Zwróci też uwagę swoim podwładnym"115. Zupełnie inną postawę prezento-

110. Ksiądz Eugeniusz Dutkiewicz..., s. 64-66.

111. J. Pałyga, Takie to było życie, Ząbki 2000, s. 149-151.

112. AKFG, Kronika, b.p.

113. AKODG, Kronika klasztoru..., b.p.

114. AKRNP, Kronika 01, s. 479.

115. AIPN Gd, sygn. 468/4/2, Meldunek operacyjny nr 708 z 15.12.81 r., k. 428. 
wał salezjanin ksiądz Stanisław Citko SDB, rektor domu i kościoła Najświętszego Serca Pana Jezusa w Gdańsku-Oruni. W rozmowie z majorem Janem Sosnowskim mówil, że władze zbyt późno zdecydowały się na wprowadzenie stanu wojennego, który „jego zdaniem skierowany jest głównie przeciwko ekstremistom «Solidarności»"116. Wydaje się jednak, że to funkcjonariusz SB włożył większość tych słów w usta zakonnika. Mało prawdopodobne, aby salezjanin mówił głosem rządowej propagandy. Podobny problem związany był $\mathrm{z}$ wypowiedzią pallotyna księdza Jerzego Błaszczyka SAC, który w rozmowie z funkcjonariuszami SB miał powiedzieć, „że jest pełen podziwu i uznania tak dla żołnierzy, jak i tych którzy odbywają służbę w ZOM0. Ksiądz ten zadeklarował, że zarówno on, jak i podlegli mu księża będą w czasie nabożeństw oddziaływać uspakajająco na wiernych". Zakonnik wypierał się w rozmowie $\mathrm{z}$ Danielem Gucewiczem nie tylko tych słów, ale i w ogóle tego, że do takiej rozmowy doszło. 0 fikcyjności słów pallotyna z raportu SB miał świadczyć - na co wskazuje historyk - brak podpisanej lojalki oraz jego późniejsza nadal nieprzychylna władzom działalność ${ }^{117}$. Rozmowę na temat zachowania jego podwładnego przeprowadzono również z ojcem Ryszardem Nowakiem OP, przełożonym klasztoru Dominikanów. Chodziło o zachowanie ojca Słomy 0P, który 15 grudnia odczytał z ambony Komunikat Rady Głównej Episkopatu Polski, w którym prymas Józef Glemp podkreślał bardzo złą sytuację gospodarczą kraju oraz przyznawał słuszność opiniom, że „W «Soli- darności» były różne kierunki, nie wszystkie godne pochwały i nie wszystkie bliskie Kościołowi, ale trudno teraz o tym mówić". Z kolei biskup Alfons Nossol stanowczo twierdzil, że opinię, jakoby wprowadzenie stanu wojennego było jedynym wyjściem, „należy zaliczyć do mitów. Władze poszły po linii najmniejszego oporu"118. Ojciec Słoma OP wygłosił przy tym negatywne wobec rządu i wprowadzenia stanu wojennego sentencje polityczne ${ }^{119}$.

20 grudnia 1981 roku podczas nietransmitowanej już mszy odprawianej przez księdza Błaszczaka "modlono się za uwięzionych i internowanych, aby ich jak najprędzej zwolniono [o] uśmierzenie cierpień rannych i za pokój dusz poległych w Katowicach". Po zakończeniu nabożeństwa w ogłoszeniach pallotyn „podał, że pieśń «Boże coś Polskę» obecnie śpiewać należy nie «0jczyznę wolną pobłogosław Panie», a stosownie do sytuacji «0jczyznę wolną racz przywrócić Panie»"120. Tego też dnia w kościele Cystersów odczytano słowa prymasa: „Błagam was bracia w imię Boga i w imię Boga zaklinam, nie podnosić nienawistnej ręki jeden przeciwko drugim. Zachowajcie spokój, nie sprowadzajcie na kraj i na naród najcięższego nieszczęścia"121. Cysters ojciec Antoni Jędrzejewski OCist., wikariusz kościoła Królowej Korony Polskiej w Gdańsku-Oliwie, obawiał się z kolei, że władze po zawieszeniu działalności Solidarności i unormowaniu sytuacji w kraju przystąpią do ograniczania swobód Kościoła. Przeor klasztoru ojciec Władysław Nycz OCist. współczuł Wałęsie, że "dał się oszukać takim doradcom jak Geremek, Kuroń, czy Modzelewski"122.

116. Salezjanin miał uważać, że wcześniejsze rozwiązanie tego problemu uchroniłoby naród przed chaosem i bezprawiem, a poniesione ofiary (między innymi podczas pacyfikacji kopalni „Wujek”) powinny być ostrzeżeniem dla tych działaczy Solidarności, którzy zmierzali do zdobycia władzy w Polsce. Jednocześnie codziennie modlił się o spokój i porządek w kraju. AIPN Gd, sygn. 468/4/2, Meldunek operacyjny mjr. mgr. Jana Sosnowskiego nr 752 z 23.12.81 r., k. 443.

117. Zob. szerzej: D. Gucewicz, W cieniu Komitetu..., s. 161.

118. Zob. szerzej: R. Łatka, Rada Główna Episkopatu Polski a stan wojenny, "Glaukopis” 2017, nr 34, s. 159-186.

119. AIPN Gd, sygn. 468/4/2, Meldunek operacyjny mjr. mgr. Jana Sosnowskiego nr 753 z 23.12 .81 r., k. 444.

120. D. Gucewicz, W cieniu Komitetu..., s. 160.

121. AKOCG0, Kronika..., s. 89.

122. AIPN Gd, sygn. 468/4/2, Meldunek operacyjny mjr. mgr. Jana Sosnowskiego nr 763 z 28.12 .81 r., k. 454. 
27 grudnia 1981 roku w kościele św. Elżbiety prowadzący mszę pallotyn odczytał list Jana Pawła II do internowanego Lecha Wałęsy, zapewniający, że papież jest z nim i z jego rodziną. Po odczytaniu listu stwierdził, odnosząc się do sytuacji społeczno-politycznej, że Polacy są karmieni półprawdami, przeinaczanymi i naciąganymi. Podkreślał, że "społeczeństwo ma prawo znać prawdę i prawdę tę musi poznać". Na koniec rozpoczął modlitwę za internowanych i ich rodziny, jak również za to, żeby w Polsce nie przelewała się krew braterska ${ }^{123}$. Tego samego dnia nabożeństwo "dla ludzi morza" odprawiał jezuita ojciec Tadeusz Pawlicki SJ, który modlił się „w intencji powrotu wolności i sprawiedliwości, wspomożenia dla rodzin ofiar wypadków oraz rychłe uwolnienie uwięzionych $\mathrm{i}$ internowanych"124. 28 grudnia 1981 roku major Jan Sosnowski z SB przeprowadził rozmowę z innym jezuitą, ojcem Józefem Wilczyńskim SJ z kościoła św. Bartłomieja, który nie ukrywał swej antypatii do przedstawiciela władz oraz do aktualnej sytuacji w kraju. Stwierdził stanowczo, że władza wojskowa działa bezprawnie oraz wydała wojnę swojemu narodowi, który chciał żyć godnie. Ojciec Wilczyński SJ wyraził swoje ogromne uznanie dla Solidarności, która była przedstawicielem niemal całego narodu. Powiedział, że nadal będzie w kazaniach potępiał niezgodne $z$ prawem, niemoralne działania, przeciwko stanowi wojennemu i WRON-ie. Odmówił również podpisania oświadczenia o lojalności, gdyż jak powiedział, Dekret Rady Państwa o wprowadzeniu stanu wojennego jest bezprawny ${ }^{125}$.
Ostatniego dnia miesiąca ksiądz Jerzy Błaszczak SAC odprawił pogrzeb jednej z pierwszych i zarazem najmłodszych ofiar stanu wojennego. Był nią Antoni Browarczyk, śmiertelnie postrzelony 17 grudnia 1981 roku w centrum Gdańska. Władze nie zgodziły się na pogrzeb w zwykłym trybie i odgórnie wyznaczono go na 31 grudnia 1981 roku ${ }^{126}$.

\section{Podsumowanie}

Tomasz Kozłowski, autor Anatomii rewolucji, zauważa, przywołując słowa Krzysztofa Wyszkowskiego, że przecenia się jednoczącą społeczeństwo rolę KościoŁa: „Powstanie «Solidarności» jest dowodem na to, że ta rola aż tak olbrzymia nie była. «Solidarność» powstała bez Kościoła. Kościół nie był wystarczającym oparciem dla samotnego, zatomizowanego społeczeństwa"127. Wydarzenia lat 1980-1981 były zaskoczeniem, a także okazją do zacieśnienia współpracy dla opozycji demokratycznej i dla Kościoła katolickiego. Na ten fakt wskazywał wielokrotnie już cytowany gdański pallotyn, ksiądz Eugeniusz Klimiński SAC, który uważał, że dawały one okazję do "śledzenia szerokiego spektrum wydarzeń i stawiania sobie pytań, jak chrześcijanie, Kościół może, powinien w nich uczestniczyć, być szkołą kształtowania się poglądów na rodzące się nowe drogi polskiego społeczeństwa"128. Jednak bez wsparcia najbardziej niezależnej od władz PRL organizacji, jaką był Kościół, moralnego oraz materialnego, tworzenie struktur Solidarności byłoby znacznie trudniejsze.

123. AIPN Gd, sygn. 468/4/2, Meldunek operacyjny nr 782 z 28.12.81 r., k. 473.

124. Ibidem.

125. AIPN Gd, sygn. 468/4/2, Meldunek operacyjny mjr. mgr. Jana Sosnowskiego nr 738 z 31.12 .81 r., k. 489.

126. D. Gucewicz, W cieniu Komitetu..., s. 161.

127. Cyt. za: T. Kozłowski, Anatomia rewolucji, s. 153.

128. Cyt. za: E. Klimiński, Do niego należy czas, s. 87. 


\section{Bibliografia}

\section{Źródła archiwalne}

Archiwum Akt Nowych:

sygn. $133 / 18$.

Archiwum Państwowe w Gdańsku:

sygn. 2375/1790.

Archiwum Instytutu Pamięci Narodowej, Oddział w Gdańsku:

sygn. $468 / 1$.

sygn. $468 / 2$.

sygn. 468/4/2.

Archiwum Klasztoru 0jców Dominikanów w Gdańsku:

Kronika klasztoru dominikanów Gdańsk 1979-1992.

Archiwum Klasztoru Franciszkanów w Gdańsku:

Kronika.

Archiwum Domu Stowarzyszenia Apostolstwa Katolickiego

w Gdańsku:

Kronika Domu, t. 2: 1976-1984.

Archiwum Klasztoru 0jcu Cystersów w Gdańsku-Oliwie:

Kronika 1945-2013 (odtworzona).

Archiwum Parafii Niepokalanego Serca Marii w Gdańsku-Wrzeszczu: Kronika parafialna (1970-1980).

Archiwum Klasztoru Reformatów w Nowym Porcie:

Kronika 01.

Archiwum Domu Zakonnego 0jców Oblatów w Gdańsku:

Kronika domu. Gdańsk 1978-1995.

Archiwum Salezjańskiej Inspektorii Pilskiej:

Teczka: Gdańsk-Orunia: Kronika działalności Pomocników Salezjańskich przy kościele Najśw. Serca Pana Jezusa w Oruni.

\section{Źródła drukowane, wspomnienia}

Bereś W., Burnetko K., Duchowny niepokorny. Rozmowy z księdzem Stanisławem Musiałem, Warszawa 2006.

Geninazzi G., Czerwona Atlantyda. Upadek komunizmu w Europie Wschodniej, przeł. A. Gołębiowska, Kraków 2014.

Klimiński E., Do niego należy czas. Pamiętnik duszpasterza, Warszawa 2007.

Ksiądz Eugeniusz Dutkiewicz SAC. Ojciec ruchu hospicyjnego w Polsce, zbiór i oprac. P. Krakowiak i A. Stolarczyk, Gdańsk 2007. Kryptonim "Klan". Służba Bezpieczeństwa wobec NSZZ "Solidarność" w Gdańsku", t. 1: wrzesień 1980 - wrzesień 1981, wstęp S. Cenckiewicz, wybór i oprac. M. Kruk, R. Żydonik, współpraca S. Cenckiewicz, Warszawa-Gdańsk 2012.
Pałyga J., Takie to było życie, Ząbki 2000.

Schematyzm Diecezji Gdańskiej rok 1980, Gdańsk 1980.

Wiśniewski L., Nigdy nie układaj się ze złem. Pięćdziesiąt lat zmagań o Kościół i Polskę, Kraków-Rzeszów 2018.

\section{Opracowania}

Bierncki L., Kazański A., NSZZ "Solidarność" Region Gdański, [w:] NSZZ Solidarność 1980-1989, t. 3: Polska północna, pod red. Ł. Kamińskiego i G. Waligóry, Warszawa 2010.

Bogdanowicz S., Lech Kaczmarek. Biskup Gdański, Gdańsk 1994. Bogdanowicz S., Kościół gdański pod rządami komunizmu 19451984, Gdańsk 2000.

Brzuszek B., 0. Dominik Norbert Kabattek OFM. Duszpasterz portowców w Gdańsku-Nowym Porcie w latach 1980-1989, "Studia Franciszkańskie" 2017, nr 17.

Czas przełomu. Solidarność 1980-1981, pod red. W. Polaka, P. Ruchlewskiego, V. Kmiecik, J. Kufla, Gdańsk 2010.

Dudek A., PRL bez makijażu, Kraków 2008.

Dudek A., Gryz R., Komuniści i Kościót w Polsce (1945-1989), Kraków 2006.

Friszke A., Rewolucja Solidarności 1980-1981, Kraków 2014.

Friszke A., Polska. Losy państwa i narodu. 1939-1989, Warszawa 2003.

Grubka M., Działania władz państwowych $i$ kościelnych wobec gdańskiego duszpasterstwa akademickiego o. Sławomira Słomy OP (1979-1985), [w:] Komunistyczny aparat represji wobec Polskiej Prowincji Dominikanów, pod red. M. Miławickiego i M. Wenklara, Kraków 2015.

Gucewicz D., W cieniu Komitetu Wojewódzkiego. „Wroga” działalność pallotynów z kościoła św. Elżbiety w Gdańsku przełomu lat siedemdziesiątych $i$ osiemdziesiątych XX wieku, [w:] Księża dla władzy groźni. Duchowni współpracujący z opozycją (1976-1989), pod red. R. Łatki, Warszawa 2019.

Gucewicz D., "Przestrzeń wolności” w Trójmieście. Dzieje gdańskiego Klubu Inteligencji Katolickiej (do 1990 r.), [w:] Kluby Inteligencji Katolickiej jako przestrzeń działań niezależnych w latach osiemdziesiatych XX wieku, pod red. K. Białeckiego, Warszawa-Poznań 2014.

Kozłowski T., Anatomia rewolucji. Narodziny ruchu społecznego "Solidarność" w 1980 roku, Warszawa 2017.

Łatka R., Episkopat Polski wobec stosunków państwo - Kościót i rzeczywistości społeczno-politycznej PRL 1970-1989, Warszawa 2019. 
Łatka R., Rada Główna Episkopatu Polski a stan wojenny, "Glaukopis" 2017, nr 34.

Łatka R., Polityka władz PRL wobec Kościoła katolickiego w województwie krakowskim w latach 1980-1989, Kraków 2016.

Marecki J., Państwo a Kościół katolicki w latach 1945-1989. Walka o "rząd dusz", [w:] Polityka władz państwowych wobec Kościoła katolickiego na Pomorzu Zachodnim i ziemi lubuskiej w latach 1945-1989, pod red. T. Ceynowy i P. Knapa, Szczecin 2010.

Mazgaj M.S., Church and State in Communist Poland. A History, 1944-1989, Jefferson-London 2010.

Michalski K., Działalność Komisji Wspólnej przedstawicieli Rządu PRL i Episkopatu Polski 1980-1989, Warszawa 2012.

Nocny W., Nowy Port. Pierwsza brama Gdańska, Gdańsk 2005. Paczkowski A., Wojna polsko-jaruzelska. Stan wojenny w Polsce 13 XII 1981 - 22 VII 1983, Warszawa 2006.

Pawłowicz Z., Kościół i Państwo w PRL 1944-1989, Gdańsk 2004. Puciłowski J., Portrety imienne i bezimienne. Polscy dominikanie a bezpieka 1945-1989, Kraków 2017.

Szarszewski A., Szarszewska A., Przełożeni domu zakonnego Braci Mniejszych Kapucynów w Gdańsku, [w:] Między Gdańskiem a Santiago. 600-lecie konsekracji kościoła św. Jakuba fundacji szyprów w Gdańsku, pod red. B. Sieka, A. Szerszewskiego, P. Paluchowskiego, Gdańsk 2015.

Zamiatała D., Zakony męskie w polityce władz komunistycznych w Polsce w latach 1945-1989, t. 2: Działalność duszpasterska i społeczna zakonów w latach 1945-1989, Warszawa 2012.

Żaryn J., Kultura niezależna w Kościele katolickim w Polsce 1981-1989. Szkic do portretu, [w:] Kościół i kultura w latach osiemdziesiątych XX wieku. Doświadczenia warszawskie, pod red.

W.A. Niewęgłowskiego, współpraca M. Romańska, KatowiceWarszawa 2014.

\section{Abstrakt}

Strajk robotników w Stoczni Gdańskiej im. Lenina w sierpniu 1980 roku oprócz znacznego poparcia społecznego spotkał się z uznaniem, wsparciem oraz pomocą ze strony jedynej niezależnej od władz komunistycznych organizacji w PRL, Kościoła katolickiego. Wśród jego przedstawicieli nie zabrakło duchownych „zza klasztornej furty” - zakonników, których na terytorium diecezji gdańskiej nie brakowało. Gdańscy dominikanie, franciszkanie konwentualni, jezuici, pallotyni, reformaci, oblaci i wielu innych w różnym zakresie oraz stopniu zaangażowania włączyli się w działania na rzecz NSZZ „Solidarność”. Działania te dotyczyły związku zawodowego oraz rodzącego się przy Solidarności ruchu społecznego. Związek i ruch otrzymały wsparcie zakonników nie tylko poprzez opiekę duszpasterską, ale również przez organizowane na ich rzecz zbiórki pieniężne, współudział oraz organizację niezależnego życia artystycznego, pisarskiego, wydawniczego czy pomoc represjonowanym członkom Solidarności i ich rodzinom.

Słowa kluczowe: Gdańsk, zakony męskie, Stocznia Gdańska, strajk, robotnicy, jezuici, pallotyni, franciszkanie konwentualni, reformaci, saletyni, salezjanie, zmartwychwstańcy, oblaci, kapucyni, karmelici bosi, księża misjonarze, cystersi

\section{Abstract}

Apart from considerable public support, the workers' strike at the Lenin Gdańsk Shipyard in August 1980 received recognition and help from the only organization independent of the communist authorities in the Polish People's Republic: the Catholic Church. Among its representatives there were some monastery clergymen - monks, of whom there were quite a few in the Gdańsk diocese. Dominican friars of Gdańsk, Conventual Franciscans, Jesuits, Pallottines, Reformists, Oblates and many others joined the activities of NSZZ (Independent Self-Governing Trade Union) "Solidarity" and were involved in one way or another. Their activities concentrated on the trade union and the social movement that was emerging around "Solidarity". The union and the movement received the support of the monks not only through pastoral care, but also through fundraising, organization, and participation in independent artistic, writing and publishing life, as well as through the help given to the repressed members of "Solidarity" and their families.

Keywords: Gdańsk, monasteries, Gdańsk Shipyard, strike, workers, Jesuits, Pallottines, Conventual Franciscans, Reformists, Saletinians, Salesians, Resurrectionists, Oblates, Capuchins, Discalced Carmelites, Cistercians, missionary priests

Leszek Molendowski (ur. 1984) - historyk, muzealnik, nauczyciel, doktor nauk humanistycznych w zakresie historii. Absolwent Wydziału Historycznego Uniwersytetu Gdańskiego. Pracownik Muzeum Gdańska. Członek Instytutu Kaszubskiego w Gdańsku. Zajmuje się historią Pomorza XIX i XX wieku, dziejami zakonów i zgromadzeń męskich. 
Leszek Molendowski (b. 1984) is a historian, museologist, and teacher. He holds a PhD in History and has graduated from the Faculty of History at the University of Gdańsk. He works for the Museum of Gdańsk, and is Member of the Kashubian Institute in Gdańsk. He deals with the history of Pomerania in the 19th and 20th century, the his tory of monasteries and congregations. 